\title{
Antibacterial activity of selenium-enriched lactic acid bacteria against common food-borne pathogens in vitro
}

\author{
Jingpeng Yang, Jing Wang, Kun Yang, Miaomiao Liu, Yiman Qi, Tingjing Zhang, Mingtao Fan, \\ and Xinyuan $\mathrm{Wei}^{1}$ \\ College of Food Science and Engineering, Northwest A\&F University, Yangling Shaanxi 712100, China
}

\begin{abstract}
Selenium (Se) is an essential trace element for human health and animal nutrition. The aim of this study was to evaluate the inhibitory activities of Se-enriched lactic acid bacteria (LAB), Lactobacillus delbrueckii ssp. bulgaricus and Streptococcus thermophilus, against pathogenic Salmonella typhimurium, Escherichia coli, Staphylococcus aureus, and Listeria monocytogenes in vitro. The results indicated that the accumulation amount of Se by Lactobacillus delbrueckii ssp. bulgaricus and Streptococcus thermophilus reached $12.05 \pm$ $0.43 \mu \mathrm{g} / \mathrm{mL}$ and $11.56 \pm 0.25 \mu \mathrm{g} / \mathrm{mL}$, respectively, accompanied by the relative maximum living cells when sodium selenite was $80 \mu \mathrm{g} / \mathrm{mL}$. Oxford cup double plate assay showed that bacterial culture solution and cell-free culture supernatant (CFCS) from Se-enriched LAB exerted stronger antibacterial activity than those from the non-Se strains. The growth of pathogenic bacterial culture with CFCS at any growth stages was worse than that without CFCS; moreover, the inhibiting effect of CFCS of Se-enriched LAB was more significant than that of non-Se strains. Results from a scanning electron microscope equipped with energy dispersion X-ray spectrometry showed that elemental Se nanoparticles, which characteristically energy peak around $1.42 \mathrm{keV}$, were deposited on the cell surfaces of Lactobacillus delbrueckii ssp. bulgaricus. In addition, CFCS of Se-enriched LAB induced more serious cell structure damage of pathogenic bacteria than did nonSe LAB.
\end{abstract}

Key words: selenium, Lactobacillus delbrueckii ssp. bulgaricus, Streptococcus thermophilus, antibacterial activity

\section{INTRODUCTION}

Diseases triggered by food-borne pathogen bacteria such as Salmonella typhimurium, Escherichia coli,

Received July 2, 2017

Accepted October 26, 2017.

${ }^{1}$ Corresponding author: wheixinyuan@yeah.net
Staphylococcus aureus, and Listeria monocytogenes are becoming serious public health problems in both developed and developing countries (Olsen et al., 2000; Tayel and El-Tras, 2010). Various approaches have been taken to address the issue, including the application of antibiotics, which is recognized as an effective way to prevent or treat pathogenic bacteria. However, resistance of pathogenic bacteria to current antibiotics is an increasing public health concern. The development of antibiotic-resistant super bacteria has resulted in currently used antibiotics failing to cure many bacterial infections, and overuse of antibiotics has caused precipitate kidney complications (Mølbak et al., 2002; Cock, 2007). Therefore, alternative strategies that could control food-borne pathogen bacteria contamination effectively and harmlessly have drawn extensive attention.

Selenium (Se), an essential trace element with a recommended dietary allowance for adults of $55 \mu \mathrm{g} / \mathrm{d}$ (tolerable upper level is $400 \mu \mathrm{g} / \mathrm{d}$ ), plays a crucial role in human health (Institute of Medicine, 2000). Previous studies have demonstrated that Se possesses potent immunoregulative, fertility-promoting, anticarcinogenic, antiaging, antioxidant, detoxification, and antibacterial activity (Navarro-Alarcón and Lopez-Martinez, 2000; Li et al., 2002; Mater et al., 2005), which indicated its potential benefit as a dietary supplement in food.

Lactic acid bacteria (LAB) play a significant role in food fermentation, where they contribute not only to the development of the desired sensory properties in the final product but also to the inhibition of harmful microbe contamination (Smaoui et al., 2010). It is difficult to avoid food-borne pathogenic bacteria in food during the processing, preservation, and transportation of products (Amer et al., 2010; Kim et al., 2016). A large part of food-borne diseases are caused by ingestion of contaminated food products, including fermented dairy products such as yogurt (Tajik et al., 2007). Lee et al. (2014) reported on a serious food-borne illness that broke out after people ingested yogurts contaminated with mold; more than 200 individuals suffered from vomiting, nausea, and diarrhea. Esena and Owusu (2013) reported on an epidemic out- 
break caused by food-borne E. coli O157:H7 in yogurt, fermented sausages, cheeses, and unpasteurized fruit juices. Considering that this problem occurs at a high frequency, much more attention should be paid to the prevention of food-borne pathogens in products.

The antibacterial effect of LAB is mainly related to the metabolites such as organic acid (mainly lactic, acetic, propionic, sorbic, and benzoic acids), hydrogen peroxide, diacetyl, ethanol, phenols, and proteinaceous compounds that are produced during the growth of the bacteria (Bajpai et al., 2016). Moreover, some strains of LAB are able to synthesize bacteriocins, which possess significant antibacterial activity (Dalie et al., 2010). Previous reports have shed light on the combination of LAB and Se that achieved a synergistic effect, exceeding the antibacterial effect of either Se or Lactobacillus acidophilus alone, both in vivo and in vitro (Yang et al., 2009). This may imply that other Se-enriched LAB might also have great potential as a novel antibacterial formula in fermented food. Plenty of studies have indicated that Se-enriched dairy products such as Se-enriched yogurt might be effective functional foods that meet the demands of Se utilization and resolve the problem of Se deficiency in some areas (Alzate et al., 2007, 2008, 2010; Palomo et al., 2014). It was reported that absorbable and high-nutritive organic se could be easily generated by microbes such as Lactobacillus brevis (Deng et al., 2015), Lactobacillus bulgaricus (Xia et al., 2007), Enterococcus faecium (Mego et al., 2005a), Enterococcus durans (Pieniz et al., 2013), Lactococcus lactis ssp. lactis (Guo et al., 2013), Lactobacillus rhamnosus, and Lactobacillus fermentum (Andreoni et al., 2000b) via microbial biotransformation during the process of fermentation.

However, comprehensive study of the activity of Seenriched LAB against food-borne pathogen bacteria is still lacking. Thus, it might be worthwhile to explore whether Se-enriched LAB have stronger inhibition against common gram-negative and gram-positive food-borne pathogenic bacteria. Lactobacillus delbrueckii ssp. bulgaricus and Streptococcus thermophilus, 2 common probiotic bacteria, have been most widely used in fermented dairy foods such as yogurt. Both can improve the flavor of dairy products as well as increase the nutritional value of fermented products, including antioxidant and antibacterial activity. In this study, the antibacterial activities of $L b$. delbrueckii ssp. bulgaricus and Strep. thermophilus, which were isolated from local yogurt and further enriched with Se, against E. coli, S. typhimurium, Staph. aureus, and L. monocytogenes were evaluated to prove that Se-enriched Lb. delbrueckii ssp. bulgaricus and Strep. thermophilus could be used as healthy starter cultures with Se supplementation to prevent the growth of food-borne pathogenic bacteria in fermented foods and improve the safety and nutritional function of dairy products.

\section{MATERIALS AND METHODS}

\section{Strains and Reagents}

Lactobacillus delbrueckii ssp. bulgaricus (XN-L) and Strep. thermophilus (XN-S), which were previously isolated from local yogurt and identified by $16 \mathrm{~S}$ rDNA analysis, were cultured in de Man, Rogosa and Sharpe (MRS) broth (Zhou et al., 2012). Escherichia coli ATCC 25922 (XN-EC), S. typhimurium LT2 ATCC 19585 (XN-LT), Staph. aureus ATCC 29213 (XNSA), and L. monocytogenes ATCC 54004 (XN-LM) were cultured in Luria-Bertani (LB) broth (Sezonov et al., 2007). All strains (stored at $-80^{\circ} \mathrm{C}$ ) were obtained from the College of Food Science and Engineering in Northwest A\&F University (Yangling, China). Sodium selenite $\left(\mathrm{Na}_{2} \mathrm{SeO}_{3}\right)$ was purchased from Tianjin Zhiyuan Chemical Engineering Factory (Tianjin, China), and 3,3'-diaminobenzidine was purchased from Tokyo Chemical Industry (Tokyo, Japan). All chemicals were analytical grade.

\section{Choice of Suitable Sodium Selenite Concentrations for $2 L A B$}

To select suitable selenite concentrations for $\mathrm{XN}-\mathrm{L}$ and XN-S to grow, the viabilities of 2 cultures in different selenite concentrations were determined by counting colony-forming units per milliliter (Deng et al., 2015). Simple colonies of XN-L and XN-S were cultivated to the post-log phase in MRS broth at $37^{\circ} \mathrm{C}$, and then $2 \%$ (vol/vol) of their cultures was transferred to $40 \mathrm{~mL}$ of MRS broth with $0,20,40,60,80,100,120,140$, or 160 $\mu \mathrm{g} / \mathrm{mL}$ of sodium selenite in $100-\mathrm{mL}$ Erlenmeyer flasks. When reaching post-log phase, $1 \mathrm{~mL}$ of aqueous solution of fermentation broth from each flask was sampled to prepare for the gradient dilutions, which then were plated on MRS agar and incubated at $37^{\circ} \mathrm{C}$ until the colonies appeared. The selenite concentrations in which $\mathrm{XN}-\mathrm{L}$ and XN-S had the highest viabilities (relative maximum) were used in the next experiments.

\section{Preparation of Se-Enriched $L A B$ and the Determination of Se Content in Cell Pellets}

The quantities of selenium accumulated by XN-L and $\mathrm{XN}-\mathrm{S}$ were determined through the mixed acid digestion method followed by detecting the optical density (OD) with a UV spectrophotometer (UV-1240, Shimadzu, Kyoto, Japan). The Se content of the digested samples could be directly measured based on OD value, 
and corresponding results were obtained through the standard curve (Kessi et al., 1999; Suhajda et al., $2000)$. Cultures $(2 \% \mathrm{vol} / \mathrm{vol})$ of $\mathrm{XN}-\mathrm{L}$ and $\mathrm{XN}-\mathrm{S}$ from MRS broth were inoculated into $40 \mathrm{~mL}$ of MRS broth with the most suitable selenite concentration at $37^{\circ} \mathrm{C}$ and cultivated to the post-log phase. The cell pellets of both Se-enriched cultures were collected by centrifugation at $6,000 \times g$ for $10 \mathrm{~min}$ and rinsed with sterile saline 3 times. Half of the cell pellets were digested with mixed acid (nitric acid:perchloric acid $=9: 1$ ) until the solution turned colorless. After the digested solutions were mixed with $0.5 \%$ (wt/vol) 3,3'-diaminobenzidine (final volume $=20 \mathrm{~mL}$ ), the yellow complex Se-3,3'diaminobenzidine was generated, which has maximum absorption peaks in methylbenzene at $420 \mathrm{~nm}$, so the Se content in the pellets could be determined by reading absorbance (Suhajda et al., 2000; Deng et al., 2015; Yang et al., 2017). Subsequently, the Se concentrations in cell cultures of XN-L and XN-S were worked out.

\section{Preparation of Bacterial Cultures, Cell-Free Culture Supernatants, and Cell Suspensions}

The cell pellets of the other half of the Se-enriched cultures were added to $20 \mathrm{~mL}$ of fresh MRS broth without sodium selenite and cultivated to their post$\log$ phase. The cultures containing the broth and cells were regarded as Se-enriched LAB (seleniumenriched Lactobacillus delbrueckii ssp. bulgaricus, XN-L-Se; selenium-enriched Streptococcusthermophilus; $\mathrm{XN-S-Se).} \mathrm{The} \mathrm{bacterial} \mathrm{cultures,} \mathrm{cell-free} \mathrm{culture}$ supernatant (CFCS), and cell suspensions of XN-L-Se and XN-S-Se were prepared for the next antibacterial tests. Ten milliliters of XN-L-Se and XN-S-Se cultures was reserved as bacterial culture samples. Subsequently, the cell pellets and supernatants of the remaining 10 $\mathrm{mL}$ of bacterial culture of XN-L-Se and XN-S-Se were collected by centrifuging at $6,000 \times g$ for $10 \mathrm{~min}$. The cell pellets were resuspended in $10 \mathrm{~mL}$ of MRS broth and named as cell suspensions. At the same time, the CFCS were obtained after the supernatant was flowed through a $0.22-\mu \mathrm{m}$ bacteria-proof membrane filter (Millipore Corp., Milford, MA). For non-Se strains (XN-L and $\mathrm{XN}-\mathrm{S}$ ), bacterial cultures, cell suspensions, and CFCS were prepared in the same way but without Se all through cultivation. All bacterial cultures and cell suspensions were diluted to about $1 \times 10^{7} \mathrm{cfu} / \mathrm{mL}$ with sterile MRS broth.

\section{Preparation of 4 Kinds of Food-Borne Pathogens}

The pathogens XN-EC, XN-LT, XN-SA, and XN-LM (stored at $-80^{\circ} \mathrm{C}$ ), which are the most common foodborne pathogens, were refreshed in LB broth with $2 \%$ (vol/vol) stored cultures for $24 \mathrm{~h}$ at $37^{\circ} \mathrm{C}$ and then were streaked on LB plates. The corresponding single colonies were selected and transferred into LB broth and cultivated to their post-log phase at $37^{\circ} \mathrm{C}$. Following that, the cultures of pathogenic bacteria were diluted to about $1 \times 10^{7} \mathrm{cfu} / \mathrm{mL}$ with sterile saline for the subsequent experiments.

\section{Antibacterial Activity Analysis of Se-Enriched LAB Against Pathogenic Bacteria In Vitro}

Six different treatment groups (sterile MRS broth, sodium selenite dissolved in MRS broth, XN-L, XN$\mathrm{S}, \mathrm{XN}-\mathrm{L}-\mathrm{Se}$, and XN-S-Se) were designed to analyze their antibacterial activity. The selenite concentration of the sodium selenite group was adjusted to the same concentration as the Se-enriched LAB, XN-L-Se, and XN-S-Se groups (bacterial cultures).

The antibacterial activities of bacterial cultures, cell suspensions, and CFCS of XN-L, XN-S, XN-L-Se, and $\mathrm{XN}-\mathrm{S}-\mathrm{Se}$ in different groups against pathogenic bacteria $\mathrm{XN}-\mathrm{EC}, \mathrm{XN}-\mathrm{LT}, \mathrm{XN}-\mathrm{SA}$, and XN-LM were tested by the Oxford cup method as reported previously (Schillinger and Lucke, 1989). Briefly, $20 \mathrm{~mL}$ of molten solid LB was poured into plates until solidification. Sterilized Oxford cups were then placed on the surface of the medium. Subsequently, another $20 \mathrm{~mL}$ of solid LB medium, melted and cooled to $50^{\circ} \mathrm{C}$, was mixed with 600 $\mu \mathrm{L}\left(1 \times 10^{7} \mathrm{cfu} / \mathrm{mL}\right)$ of pathogenic bacteria and poured on the bottom layer. The Oxford cups were carefully taken out after the medium solidified, and then $200 \mu \mathrm{L}$ of sterile MRS broth, sodium selenite solution, bacterial cultures, cell suspensions, and CFCS of XN-L, XN$\mathrm{S}, \mathrm{XN}-\mathrm{L}-\mathrm{Se}$, and XN-S-Se was loaded into the holes and cultivated at $37^{\circ} \mathrm{C}$ for $24 \mathrm{~h}$ after the samples diffused for $3 \mathrm{~h}$ at $4^{\circ} \mathrm{C}$. Finally, the diameters of the inhibition zones on all plates were measured.

\section{Effect of CFCS of 2 Se-Enriched LAB on the Growth of Pathogenic Bacteria}

After $1 \mathrm{~mL}$ of CFCS of XN-L, XN-S, XN-L-Se, and $\mathrm{XN}-\mathrm{S}-\mathrm{Se}$, respectively, was added to the tubes containing $4 \mathrm{~mL}$ of pathogenic bacteria solutions $\left(1 \times 10^{7} \mathrm{cfu} /\right.$ $\mathrm{mL}$ ) and cultivated at $37^{\circ} \mathrm{C}$ for $24 \mathrm{~h}$, the absorbance of the samples at $600 \mathrm{~nm}$ was measured every $2 \mathrm{~h}$ to obtain the growth curves of 4 pathogenic bacteria. The growth curves of $1 \mathrm{~mL}$ of sterile saline mixed with 4 $\mathrm{mL}$ of pathogenic bacteria solution were regarded as the controls.

\section{Surface Morphology Analysis of Se-Enriched LAB}

The cell pellets of XN-L-Se and XN-S-Se were collected by centrifugation at $6,000 \times g$ for $10 \mathrm{~min}$ and 
then were mixed with $2.5 \%$ (wt/vol) glutaraldehyde for $3 \mathrm{~h}$. Then, the precipitates were rinsed twice with phosphate buffer ( $\mathrm{pH} 7.2$ ) for 20 min. The samples were then dehydrated by gradient alcohol solution concentration from $50 \%$ to $100 \%$. The dry samples were subjected to ion sputtering coating (IB-3, Eiko, Tokyo, Japan). The surface morphology of prepared samples was examined using a scanning electron microscope (S4800, Hitachi Ltd., Tokyo, Japan), and the chemical composition of the selected area was determined using X-ray spectrometry (EX-250, Horiba Ltd., Seoul, South Korea).

\section{Effect of CFCS of 2 Se-Enriched LAB on the Cell Structures of Pathogenic Bacteria}

To verify the antibacterial effects of CFCS of XN-LSe and XN-S-Se on the pathogenic bacteria, the CFCS of XN-L, XN-S, XN-L-Se, and XN-S-Se were mixed with pathogenic bacterial culture solution $\left(1 \times 10^{7} \mathrm{cfu} /\right.$ $\mathrm{mL}$ ) in a proportion of 1:10 (vol/vol) for $16 \mathrm{~h}$. The pathogenic cell pellets were collected by centrifugation at $6,000 \times g$ for $10 \mathrm{~min}$. The cell pellets were then processed according to the treating processes of Seenriched LAB (described above). The surface morphology and cell structures of pathogenic bacteria samples were examined using a scanning electron microscope (S-4800, Hitachi Ltd.).

\section{Statistical Analysis}

Each assay was performed in triplicate, and data were expressed as means \pm standard deviation. The differences between the groups were examined by one-way ANOVA using Minitab 16.2.3 software (Minitab Inc., State College, PA). A $P$-value of $<0.05$ was considered statistically significant.

\section{RESULTS}

\section{Confirmation of Suitable Sodium Selenite Concentrations for Se Enrichment of $L A B$}

Effects of sodium selenite concentration on cell growth of XN-L and XN-S were determined by counting colony-forming units per milliliter. Both XN-L and XN-S were cultivated in MRS broth containing different concentrations of sodium selenite to their post-log phase at $37^{\circ} \mathrm{C}$ and then were smeared on MRS plates after gradient dilution until colonies were clearly visible at $37^{\circ} \mathrm{C}$. Result showed that the number of colonyforming units per milliliter of both cultures increased steadily with the increase of selenite concentration up to $80 \mu \mathrm{g} / \mathrm{mL}$, but their growth decreased gradually with the further heightening of selenite concentrations from $80 \mu \mathrm{g} / \mathrm{mL}$ to $160 \mu \mathrm{g} / \mathrm{mL}$ (Table 1). According to viabilities of $\mathrm{XN}-\mathrm{L}$ and $\mathrm{XN}-\mathrm{S}$ in different selenite concentrations, low concentrations of selenite could promote the growth of 2 kinds of LAB, but once the concentration of selenite reached or exceeded a certain level, the amount of living cells decreased distinctly. Analysis of variance showed that the number of living $\mathrm{XN}-\mathrm{L}$ and XN-S cells simultaneously reached the relative maximum of $8.82 \pm 0.04$ and $8.87 \pm 0.03 \mathrm{log} \mathrm{cfu} /$ $\mathrm{mL}$, respectively, when the selenite concentration was $80 \mu \mathrm{g} / \mathrm{mL}$. Therefore, $80 \mu \mathrm{g} / \mathrm{mL}$ of sodium selenite was regarded as the relative suitable selenite concentration for XN-L and XN-S to accumulate Se in subsequent experiments.

\section{Corresponding Se Concentrations Enriched by LAB}

The corresponding concentrations of Se that were assimilated by XN-L and XN-S were calculated after the quantity of Se in cell pellets centrifuged from their cultures was measured by reading the absorbance of the Se-3,3'-diaminobenzidine yellow complex in methylbenzene at $420 \mathrm{~nm}$. The results showed that the Se concentrations enriched by XN-L and XN-S were 12.05 \pm 0.43 and $11.56 \pm 0.25 \mu \mathrm{g} / \mathrm{mL}$ (data not shown), respectively, when 2 cultures were cultivated in MRS broth with $80 \mu \mathrm{g} / \mathrm{mL}$ of sodium selenite. The other half of the cultures of Se-enriched XN-L and XN-S were prepared for Se-enriched LAB.

\section{Antibacterial Activities of Different Compositions of $X N-L, X N-S, X N-L-S e$, and $X N-S-S e$ In Vitro}

Based on the results of preparation of Se-enriched $\mathrm{LAB}$, the Se concentration of sodium selenite for the

Table 1. Effect of different concentrations of sodium selenite on lactic acid bacteria growth ${ }^{1,2}(\log \mathrm{cfu} / \mathrm{mL})$

\begin{tabular}{lll}
\hline $\begin{array}{l}\text { Sodium selenite } \\
(\mu \mathrm{g} / \mathrm{mL})\end{array}$ & \multicolumn{1}{c}{ XN-L } & XN-S \\
\hline 0 & $8.80 \pm 0.01^{\mathrm{ab}}$ & $8.84 \pm 0.02^{\mathrm{a}}$ \\
20 & $8.79 \pm 0.01^{\mathrm{ab}}$ & $8.84 \pm 0.02^{\mathrm{a}}$ \\
40 & $8.79 \pm 0.02^{\mathrm{abc}}$ & $8.83 \pm 0.03^{\mathrm{ab}}$ \\
60 & $8.80 \pm 0.04^{\mathrm{ab}}$ & $8.84 \pm 0.03^{\mathrm{a}}$ \\
80 & $8.82 \pm 0.04^{\mathrm{a}}$ & $8.87 \pm 0.03^{\mathrm{a}}$ \\
100 & $8.75 \pm 0.03^{\mathrm{bcd}}$ & $8.81 \pm 0.03^{\mathrm{ab}}$ \\
120 & $8.73 \pm 0.02^{\mathrm{cd}}$ & $8.80 \pm 0.07^{\mathrm{ab}}$ \\
140 & $8.72 \pm 0.01^{\mathrm{d}}$ & $8.77 \pm 0.04^{\mathrm{b}}$ \\
160 & $7.55 \pm 0.07^{\mathrm{e}}$ & $7.68 \pm 0.03^{\mathrm{c}}$ \\
\hline
\end{tabular}

${ }^{\mathrm{a}-\mathrm{e}}$ Means in the same column with different superscripts are significantly different $(P<0.05)$.

${ }^{1}$ Values are means $\pm \mathrm{SD}$.

${ }^{2} \mathrm{XN}-\mathrm{L}=$ Lactobacillus delbrueckii $\mathrm{ssp}$. bulgaricus; $\mathrm{XN}-\mathrm{S}=$ Streptococcus thermophilus. 
Table 2. Inhibitory effect (diameter of inhibition zone, $\mathrm{mm}$ ) of lactic acid bacteria on indicator bacteria ${ }^{1,2}$

\begin{tabular}{|c|c|c|c|c|}
\hline \multirow[b]{2}{*}{ Group } & \multicolumn{4}{|c|}{ Indicator bacteria } \\
\hline & $\mathrm{XN}-\mathrm{EC}$ & XN -LM & XN-LT & $\mathrm{XN}-\mathrm{SA}$ \\
\hline Sterile saline & $7.00 \pm 0.21^{\mathrm{h}}$ & $7.00 \pm 0.06^{\mathrm{g}}$ & $7.00 \pm 0.67^{\mathrm{g}}$ & $7.00 \pm 0.15^{\mathrm{g}}$ \\
\hline Sodium selenite & $7.12 \pm 0.45^{\mathrm{h}}$ & $7.15 \pm 0.12^{\mathrm{g}}$ & $7.23 \pm 0.91^{\mathrm{g}}$ & $33.01 \pm 0.22^{\mathrm{a}}$ \\
\hline \multicolumn{5}{|l|}{ CFCS } \\
\hline XN-L & $16.22 \pm 1.09^{\mathrm{e}}$ & $13.12 \pm 0.07^{\mathrm{e}}$ & $17.59 \pm 0.11^{\mathrm{bc}}$ & $14.87 \pm 0.20^{\mathrm{f}}$ \\
\hline $\mathrm{XN}-\mathrm{S}$ & $19.05 \pm 0.22^{\mathrm{cd}}$ & $12.95 \pm 0.43^{\mathrm{e}}$ & $17.78 \pm 0.43^{\mathrm{bc}}$ & $15.51 \pm 0.31^{\mathrm{ef}}$ \\
\hline XN-S-Se & $17.56 \pm 0.78^{\mathrm{de}}$ & $16.44 \pm 0.42^{\mathrm{ab}}$ & $18.26 \pm 0.11^{\mathrm{b}}$ & $16.42 \pm 0.39^{\mathrm{e}}$ \\
\hline XN-L-Se & $18.25 \pm 0.19^{\mathrm{d}}$ & $14.15 \pm 0.18^{\mathrm{de}}$ & $17.15 \pm 0.14^{\mathrm{cd}}$ & $15.79 \pm 0.44^{\mathrm{ef}}$ \\
\hline \multicolumn{5}{|l|}{ Cell suspension } \\
\hline XN-L & $8.05 \pm 0.08^{\mathrm{g}}$ & $11.09 \pm 0.71^{\mathrm{f}}$ & $7.25 \pm 0.51^{\mathrm{f}}$ & $7.00 \pm 0.26^{\mathrm{g}}$ \\
\hline $\mathrm{XN}-\mathrm{S}$ & $7.87 \pm 0.56^{\mathrm{f}}$ & $7.01 \pm 0.09^{\mathrm{g}}$ & $7.09 \pm 0.17^{\mathrm{f}}$ & $7.00 \pm 0.23^{\mathrm{g}}$ \\
\hline $\mathrm{XN}-\mathrm{S}-\mathrm{Se}$ & $7.54 \pm 0.77^{\mathrm{fg}}$ & $8.12 \pm 0.01^{\mathrm{g}}$ & $7.55 \pm 0.88^{\mathrm{e}}$ & $7.00 \pm 0.41^{\mathrm{g}}$ \\
\hline XN-L-Se & $7.45 \pm 0.41^{\mathrm{fg}}$ & $7.69 \pm 0.01^{\mathrm{g}}$ & $7.01 \pm 0.86^{\mathrm{e}}$ & $7.00 \pm 0.33^{\mathrm{g}}$ \\
\hline \multicolumn{5}{|c|}{ Bacterial culture solution } \\
\hline XN-L & $21.05 \pm 0.29^{\mathrm{a}}$ & $17.52 \pm 0.32^{\mathrm{bc}}$ & $17.05 \pm 0.73^{\mathrm{a}}$ & $17.52 \pm 0.97^{\mathrm{d}}$ \\
\hline $\mathrm{XN}-\mathrm{S}$ & $20.05 \pm 0.55^{\mathrm{c}}$ & $15.05 \pm 0.38^{\mathrm{cd}}$ & $14.89 \pm 0.39^{\mathrm{a}}$ & $18.56 \pm 0.10^{\mathrm{c}}$ \\
\hline XN-S-Se & $23.22 \pm 0.64^{\mathrm{ab}}$ & $16.12 \pm 0.34^{\mathrm{abc}}$ & $16.45 \pm 0.42^{\mathrm{d}}$ & $20.05 \pm 0.35^{\mathrm{b}}$ \\
\hline XN-L-Se & $22.23 \pm 0.62^{\mathrm{b}}$ & $16.99 \pm 0.56^{\mathrm{a}}$ & $16.49 \pm 0.31^{\mathrm{d}}$ & $18.05 \pm 0.06^{\mathrm{cd}}$ \\
\hline
\end{tabular}

control in the antibacterial experiments was adjusted to $12 \mu \mathrm{g} / \mathrm{mL}$ to achieve the same Se level. The experiments were carried out to detect the antibacterial activities of different compositions of LAB with or without Se. The results showed that all CFCS and bacterial culture solutions of XN-L, XN-S, XN-L-Se, and XN-S-Se were bactericidal against XN-EC, XN-LT, XN-SA, and XNLM (Table 2).

Data from the inhibition zone showed significant differences $(P<0.05)$ among bacterial culture solutions, CFCS, and cell suspensions. For example, the bacterial culture solution of XN-L against XN-EC displayed the largest inhibition zone $(21.05 \pm 0.29 \mathrm{~mm})$; the inhibition zones of CFCS and the cell suspension were 16.22 $\pm 1.09 \mathrm{~mm}$ and $8.05 \pm 0.08 \mathrm{~mm}$, respectively. The bacterial culture solutions clearly had the strongest antibacterial capacity among the different compositions, and the CFCS were second strongest; the cell suspensions had the least effects on pathogenic bacterial growth (Figure 1). The cell suspensions of XN-L and XN-S could hardly inhibit XN-EC, XN-LT, and XN-SA, whereas XN-LM could be slightly inhibited by cell suspension of Se-enriched LAB. Furthermore, the antibacterial activities of Se-enriched LAB were stronger than those of non-Se strains. The inhibition zone of bacterial culture solution of XN-L-Se against XN-SA was $18.05 \pm 0.06 \mathrm{~mm}(\mathrm{XN}-\mathrm{L}, 17.52 \pm 0.97 \mathrm{~mm})$, that of XN-L-Se CFCS was $15.79 \pm 0.44 \mathrm{~mm}$ (XN-L, 14.87 $\pm 0.20 \mathrm{~mm}$ ), and that of the cell suspension of XN-L-Se was $7.00 \pm 0.33 \mathrm{~mm}(\mathrm{XN}-\mathrm{L}, 7.00 \pm 0.26 \mathrm{~mm}$; Table 2). In addition, $12 \mu \mathrm{g} / \mathrm{mL}$ of sodium selenite exerted excellent antibacterial activity to XN-SA (Figure 1), the inhibition zone of which reached $33.01 \pm 0.22 \mathrm{~mm}$, exceeding that of the XN-S-Se bacterial culture solution $(20.05 \pm 0.35 \mathrm{~mm}$; Table 2). As a whole, Se-enriched LAB exerted outstanding antibacterial activity in comparison with that of non-Se LAB on these 4 food-borne pathogenic bacteria.

\section{Effect of CFCS of Se-Enriched LAB on the Growth of Pathogenic Bacteria}

After equal volumes of CFCS from XN-L, XN-S, XN-L-Se, and XN-S-Se (equal volume of MRS broth replacing CFCS as the control) were added to bacterial culture solutions $\left(1 \times 10^{7} \mathrm{cfu} / \mathrm{mL}\right)$ of XN-EC, XN-LT, $\mathrm{XN}-\mathrm{SA}$, and XN-LM, respectively, the growth curves of 4 pathogenic bacteria were determined (Figure 2). The results in Figure 2a to d demonstrate that the growth of pathogenic bacteria mixed with CFCS showed delays. At h 16 in the post-log phases, the OD of XN-EC with CFCS of XN-L, XN-S, XN-L-Se, and XN-S-Se was $1.6344,1.6906,1.3628$, and 1.3828 , respectively, whereas the OD of the corresponding control was 1.9125. The OD of XN-LM with CFCS of XN-L, XN-S, XN-L-Se, and XN-S-Se was 1.1144, 1.1572, 1.0628, and 0.9628, respectively, and the OD of the corresponding control was 1.3125. The OD of XN-LT with CFCS of XN-L, XN-S, 
$\mathrm{XN}-\mathrm{L}-\mathrm{Se}, \mathrm{XN}-\mathrm{S}-\mathrm{Se}$, and the corresponding control were $0.7844,0.7572,0.2228,0.2328$, and 1.1212 , respectively. The OD were $1.5844,1.4772,1.0628,1.2750$, and 2.0925 for XN-SA with CFCS of XN-L, XN-S, XN-L-Se, XN$\mathrm{S}-\mathrm{Se}$, and the corresponding control, respectively. It was found that CFCS of both LAB (Se-enriched or non-Se) had obvious antibacterial activities against the 4 pathogens; moreover, the Se-enriched LAB possessed stronger inhibiting capacity. Further, comparison of OD values in different mixed cultures, based on significant analysis $(P<0.05)$, showed significant difference. As a whole, the OD values of pathogenic bacterial culture growing with CFCS at any growth stages were less than those of the control group.

\section{Surface Feature of Se-Enriched LAB by Scanning Electron Microscopy}

The surface morphology of Se-enriched LAB was surveyed from the cell suspensions using scanning electron microscopy with energy dispersion X-ray (EDX) spectrometry. Many particle deposits were
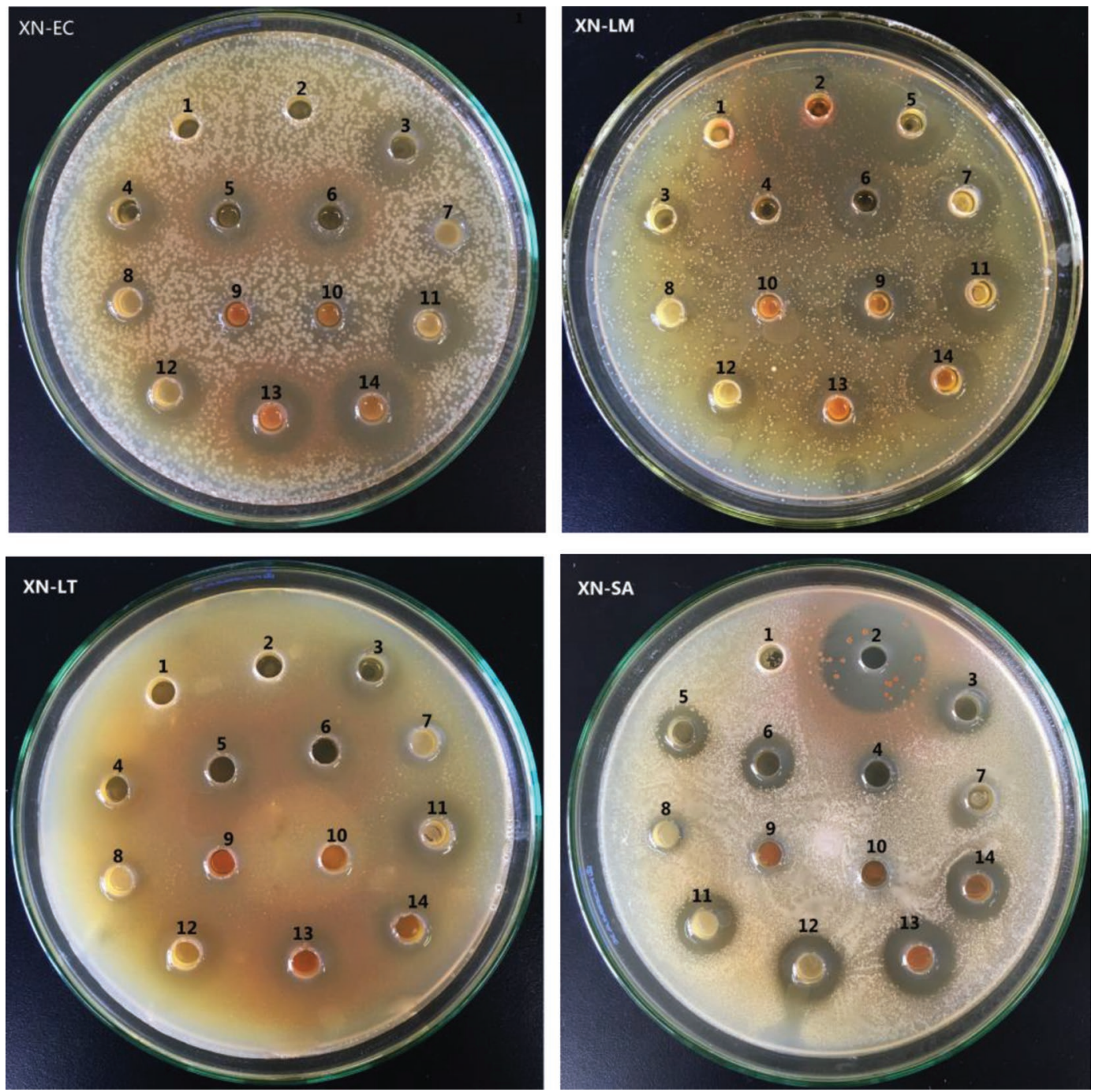

Figure 1. Inhibitory effect of bacterial culture solution, cell suspension, and cell-free culture supernatant (CFCS) in different groups on pathogenic bacteria: (1) sterile de Man, Rogosa and Sharpe (MRS) broth (control), (2) sodium selenite (12 $\mu \mathrm{g} / \mathrm{mL})$ in MRS broth, (3) CFCS of XN-L, (4) CFCS of XN-S, (5) CFCS of XN-S-Se, (6) CFCS of XN-L-Se, (7) cell suspension of XN-L, (8) cell suspension of XN-S, (9) cell suspension of XN-S-Se, (10) cell suspension of XN-L-Se, (11) bacterial culture solution of XN-L, (12) bacterial culture solution of XN-S, (13) bacterial culture solution of XN-S-Se, and (14) bacterial culture solution of XN-L-Se. XN-EC = Escherichia coli ATCC 25922; XN-LM = Listeria monocytogenes ATCC 54004; XN-LT = Salmonella typhimurium LT2 ATCC 19585; XN-SA = Staphylococcus aureus ATCC 29213; XN-L = Lactobacillus delbrueckii ssp. bulgaricus; XN-S = Streptococcus thermophilus; XN-S-Se = selenium-enriched Streptococcus thermophilus; XN-L-Se = selenium-enriched Lactobacillus delbrueckii ssp. bulgaricus. Color version available online. 
found scattering around the cell surface of XN-L-Se and XN-S-Se after both LAB were cultivated in MRS broth with $80 \mu \mathrm{g} / \mathrm{mL}$ of selenite (Figure 3). To further determine the chemical characteristics of the deposits, the elemental analysis of XN-L-Se was performed using an EDX spectroscope (Figure 4). Results showed that the characteristic energy peak of the Se nanoparticle $(1.42 \mathrm{keV})$ was discovered around the cell surfaces of XN-L-Se. Similar scanning electron micrographs were also obtained with the cells from XN-S-Se (data not shown). These phenomena suggest that LAB reduced toxic selenite to elemental Se.

\section{Antibiotic Characteristics of CFCS of Se-Enriched $L A B$ on the Cell Structures of Pathogenic Bacteria}

How did the CFCS of LAB inhibit the growth of pathogenic bacteria XN-EC, XN-LT, XN-SA, and XN-LM? Scanning electron microscopy was applied to detect whether the cell structures of these pathogenic bacteria were damaged by the CFCS of XN-L-Se and $\mathrm{XN}-\mathrm{S}-\mathrm{Se}$. The cell structures of these pathogenic bacteria could be easily revealed by microscopy. Compared with the intact morphology cells of controls (without CFCS; Figure 5a, d, g, and j), the cell morphology of 4 pathogenic bacteria mixed with CFCS of XN-S showed a shrunken norphology, cytoplasm leakage, and dissolved structure (Figure 5b, e, h, and k). The cell morphology of pathogens cultivated in CFCS of XNS-Se had greater changes, including the change of cell surface morphology and the dissolution of the cell wall. The results indicated that the CFCS of XN-S-Se had a more powerful influence on the pathogenic bacteria than that of XN-S. Similar results were also observed for pathogenic bacteria cells mixed with CFCS from XN-L and XN-L-Se (data not shown). Therefore, it implied that the CFCS of Se-enriched LAB could have higher antibiotic activities on the 4 pathogenic bacteria than non-Se LAB.
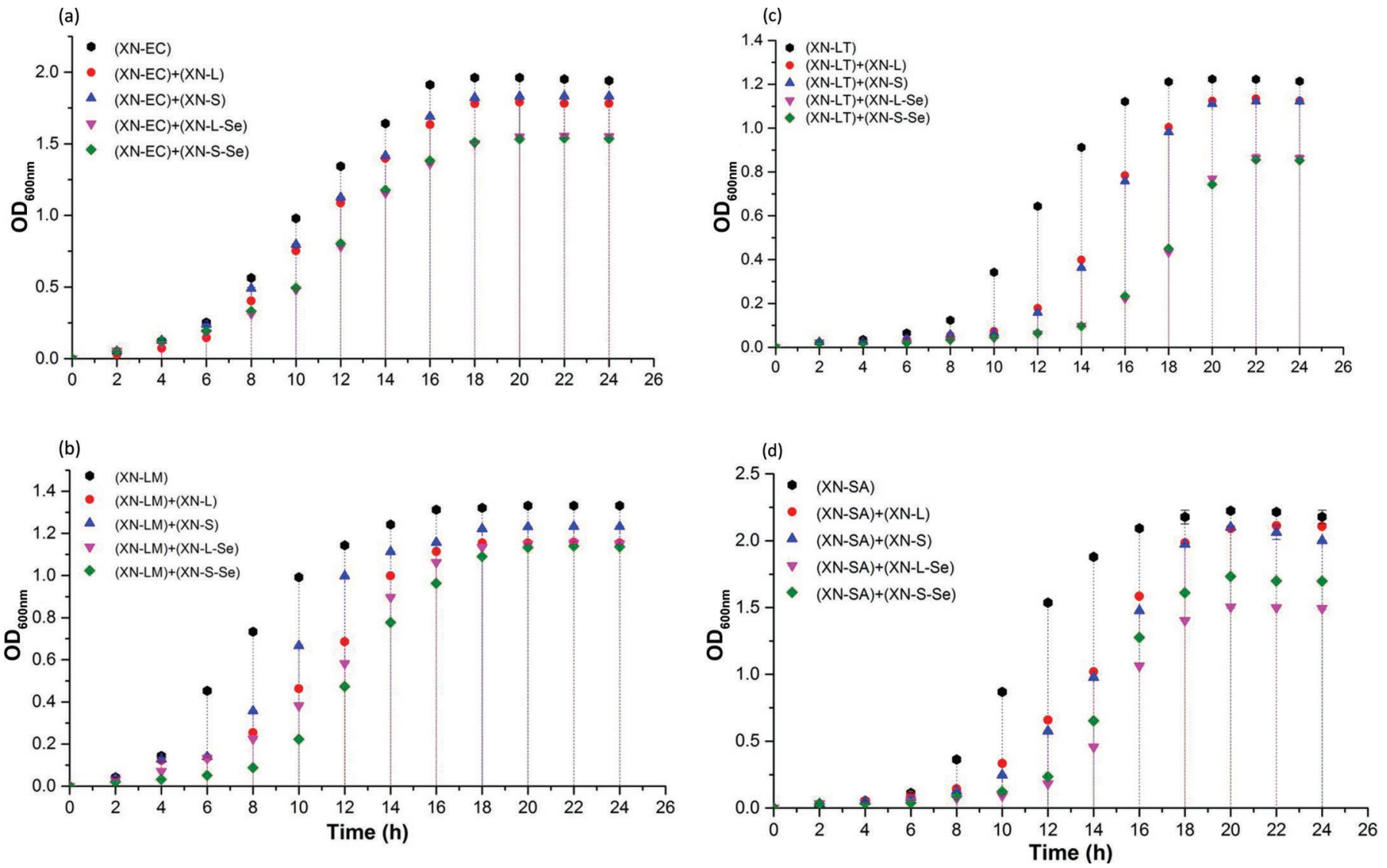

Figure 2. Growth curves of pathogenic bacteria coincubated with cell-free culture supernatant (CFCS): (a) CFCS + XN-EC, (b) CFCS + XN-LM, (c) CFCS + XN-LT, (d) CFCS + XN-SA. XN-EC = Escherichia coli ATCC 25922; XN-LM = Listeria monocytogenes ATCC 54004; $\mathrm{XN}-\mathrm{LT}=$ Salmonella typhimurium LT2 ATCC 19585; XN-SA = Staphylococcus aureus ATCC 29213; XN-L = Lactobacillus delbrueckii ssp. bulgaricus; XN-S = Streptococcus thermophilus; XN-L-Se = selenium-enriched Lactobacillus delbrueckii ssp. bulgaricus; XN-S-Se = seleniumenriched Streptococcus thermophilus. Color version available online. 


\section{DISCUSSION}

Dairy products are popular consumer goods, especially yogurt, which has high quality proteins and AA and contains probiotic bacteria such as Lb. delbrueckii ssp. bulgaricus and Strep. thermophilus. However, foodborne pathogenic bacteria - one of the most serious hazards in the dairy industry - result in a decrease in the nutritive value of food, a threat to human health, and economic losses (Kouamé-Sina et al., 2012; Timm et al., 2013; McAuley et al., 2014; Bernini et al., 2015; Dalzini et al., 2016).

Selenium deficiency is a serious health problem that still exists in some areas in China. Selenium is lacking in some local areas, and most Se exists in inorganic

(a)

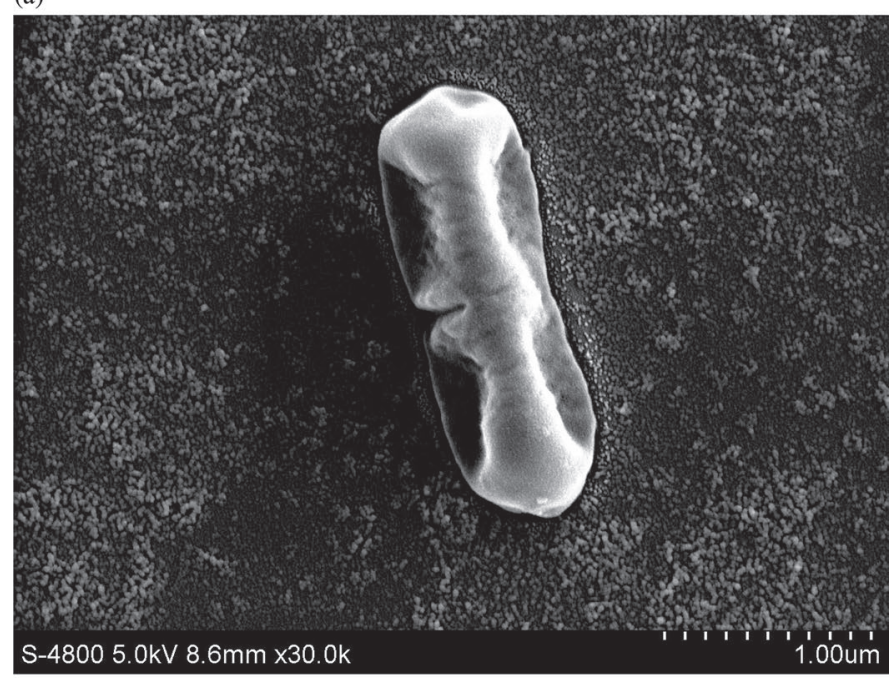

(b)

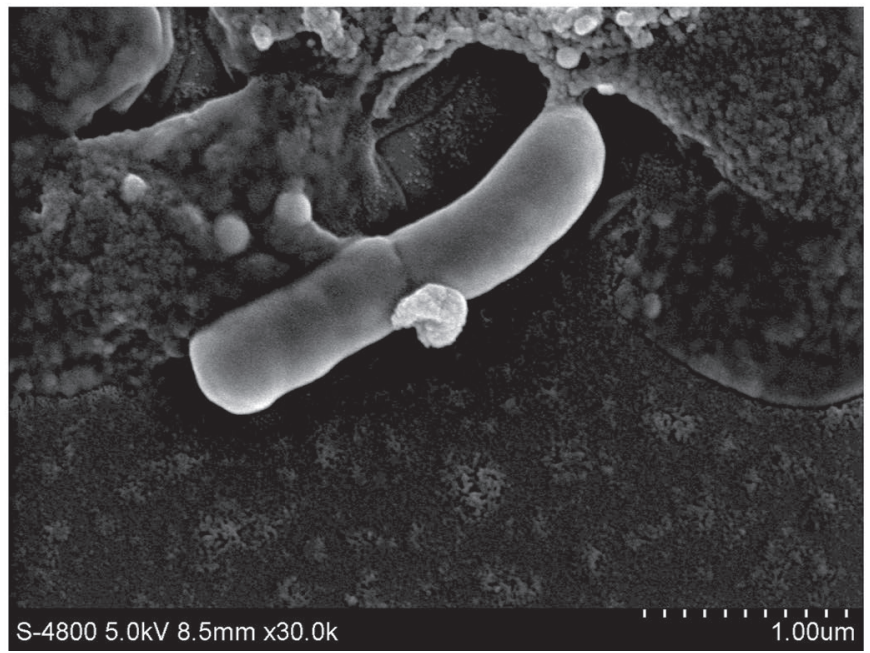

Figure 3. The morphology of selenium-enriched Lactobacillus delbrueckii ssp. bulgaricus (XN-L-Se) by scanning electron microscope analysis: (a) control (XN-L); (b) selenium enriched (XN-L-Se). forms, which are difficult for people to effectively absorb and utilize. Organic Se, however, is absorbable and healthful (Kieliszek and Blazejak, 2013). Microorganisms such as yeast could save more absorbable organic Se such as selenoprotein and selenocystine by incorporating the inorganic Se ions into a cellular biomass from the surrounding environment. These similar properties have also been found in LAB (Andreoni et al., 2000a; Mogna et al., 2012; Kieliszek and Blazejak, 2013). Selenium coupled with probiotic bacteria has already been applied in fermented foods, which could provide nutritional Se as well as antioxidant activity (Reid and Burton, 2002; Penas et al., 2012b). The an-

(a)

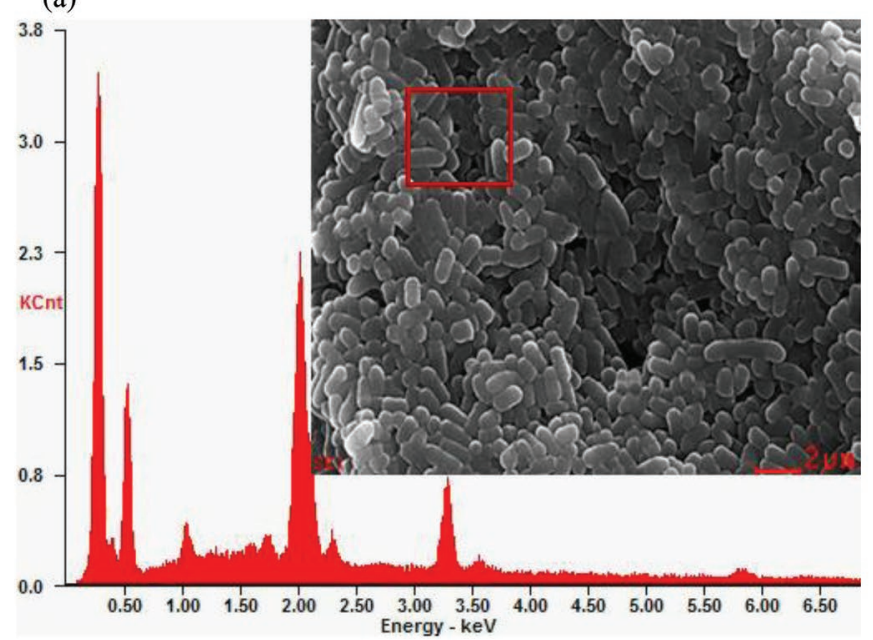

(b)

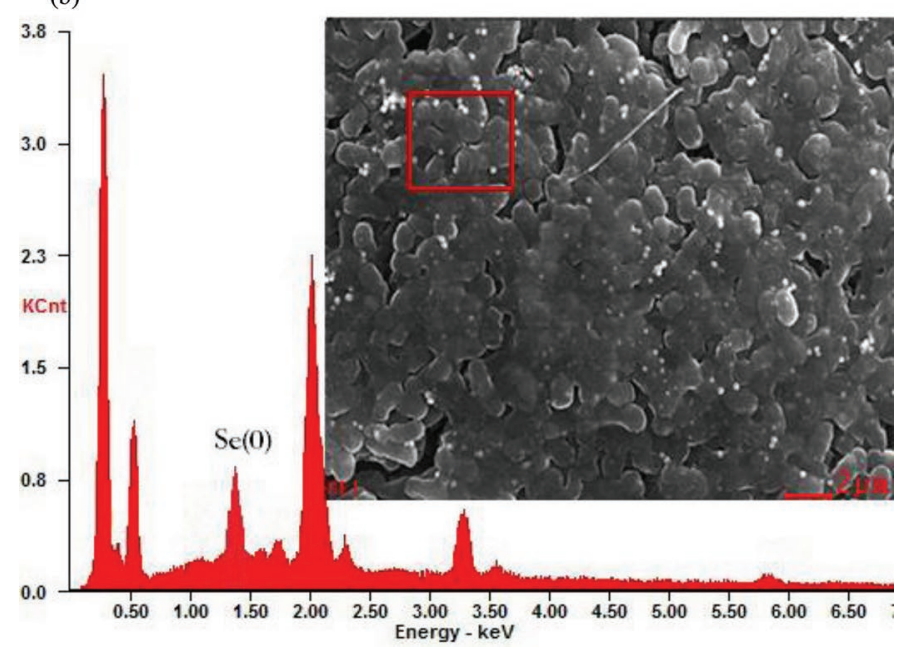

Figure 4. Analysis of a scanning electron microscope equipped with energy dispersion X-ray (EDX) on the cells of lactic acid bacteria in $80 \mu \mathrm{g} / \mathrm{mL}$ of selenite: (a) control (XN-L); (b) selenium (Se) nanoparticles dispensed around the cells (XN-L-Se). The EDX spectrum on Se nanoparticles indicates an Se (0) characteristic peak near $1.42 \mathrm{keV} . \mathrm{K}=1,000, \mathrm{Cnt}=$ counts. Color version available online. 
(a)

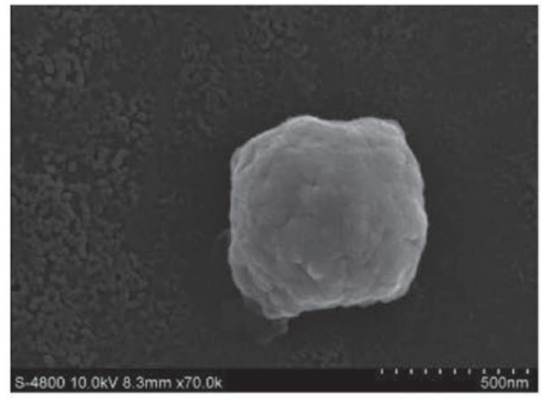

(d)

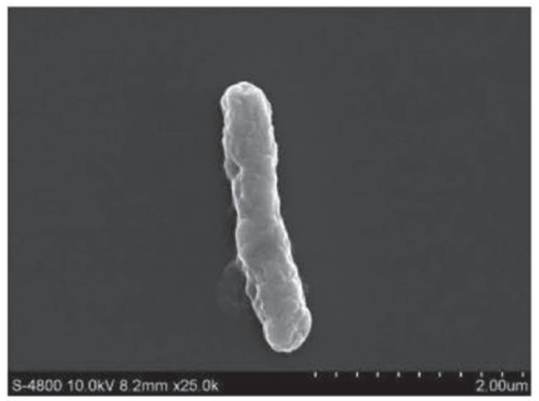

(g)

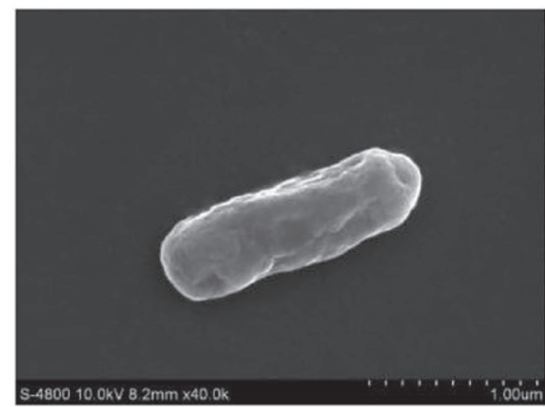

(j)

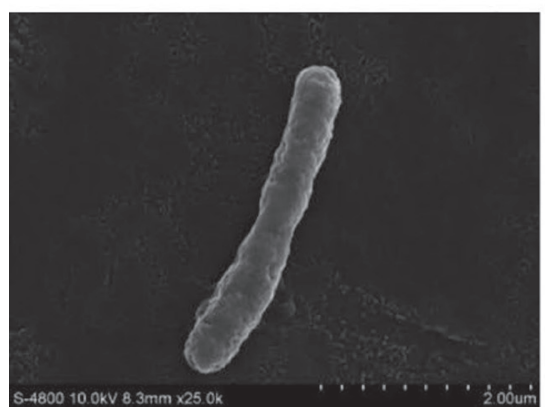

(b)

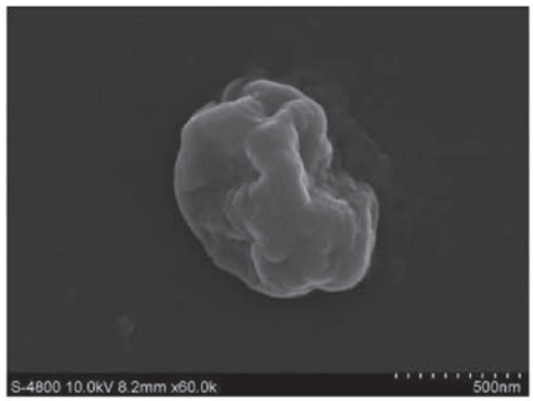

(e)

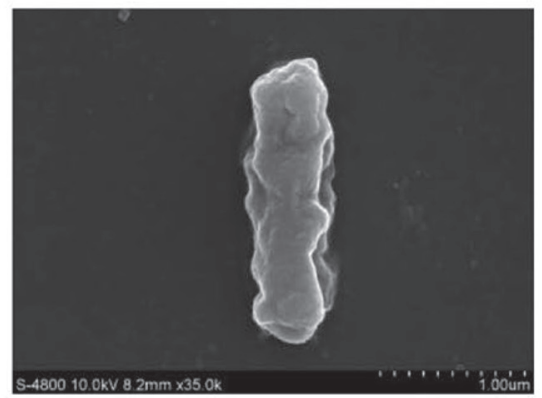

(h)

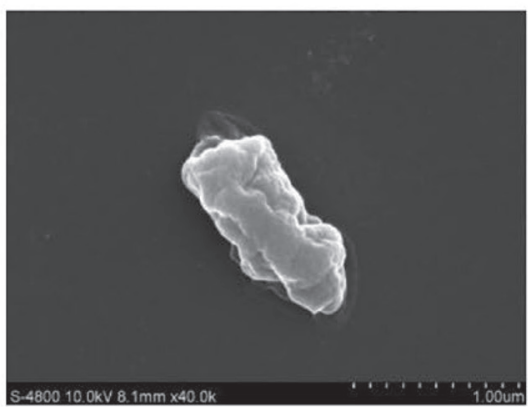

(k)

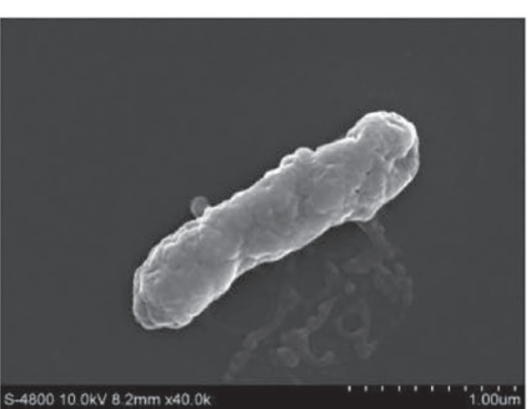

(c)

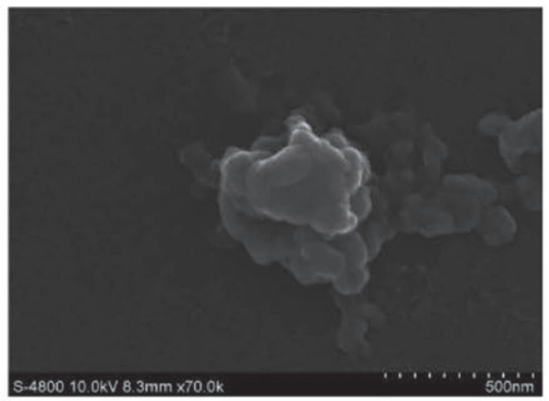

(f)

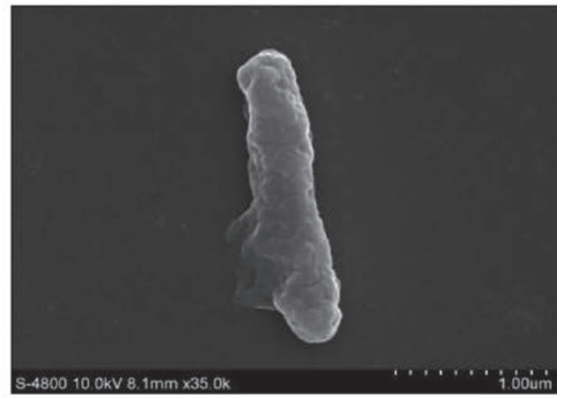

(i)

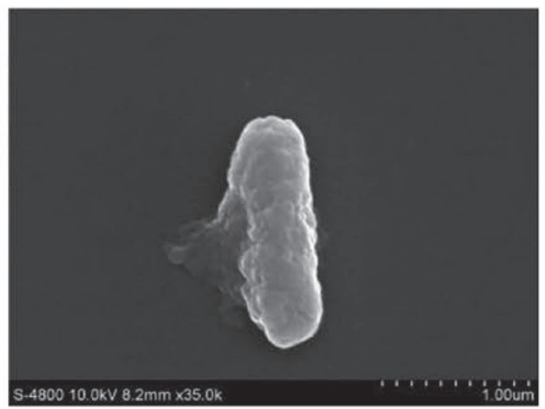

(I)

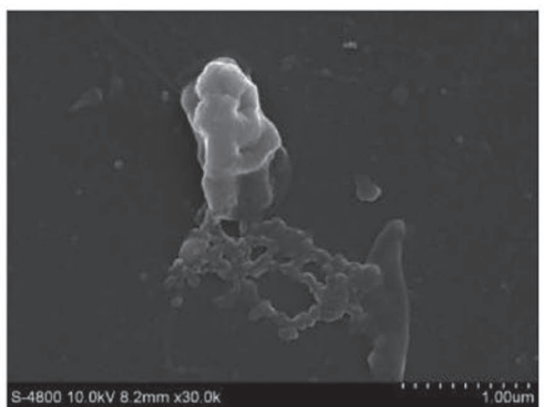

Figure 5. Cell structures of 4 kinds of pathogenic bacteria coincubated with cell-free culture supernatant CFCS from XN-S and XN-S-Se: (a) XN-SA, (b) XN-SA + CFCS, (c) XN-SA + selenium (Se)-enriched CFCS, (d) XN-LT, (e) XN-LT + CFCS, (f) XN-LT + Se-enriched CFCS, (g) XN-LM, (h) XN-LM + CFCS, (i) XN-LM + Se-enriched CFCS, (j) XN-EC, (k) XN-EC + CFCS, and (l) XN-EC + Se-enriched CFCS. XN-EC = Escherichia coli ATCC 25922; XN-LM = Listeria monocytogenes ATCC 54004; XN-LT = Salmonella typhimurium LT2 ATCC 19585; XN-SA = Staphylococcus aureus ATCC 29213; XN-S = Streptococcus thermophilus; XN-S-Se = Se-enriched Streptococcus thermophilus. 
tibacterial activity of LAB is a popular issue, but few studies have examined the antibacterial activity of Seenriched LAB. Therefore, the antibacterial activities of Se-enriched XN-L and XN-S against food-borne pathogens such as E. coli, S. typhimurium, Staph. aureus, and L. monocytogenes were evaluated in this study. The results demonstrated that Se-enriched XN-L and XN-S had stronger antibacterial activities than non-Se strains in vitro.

Selenium fulfills various important physiologic functions through its antioxidant and antibacterial activity as well as its direct effect on the growth of the organism, which was thought of as one critical factor of biological metabolism (Kieliszek et al., 2016b). However, once the concentration of Se exceeds the tolerance limits, it does harm to the organism (Kieliszek and Blazejak, 2013). Kieliszek et al. (2016b) reported that Candida utiliz yeast reached its highest biomass yield after $24 \mathrm{~h}$ of cultivation in the presence of $10 \mu \mathrm{g} / \mathrm{mL}$ of $\mathrm{Se}^{4+}$, but it was strongly inhibited by higher concentrations $(60 \mu \mathrm{g} /$ $\mathrm{mL}$ of $\left.\mathrm{Se}^{4+}\right)$. Meanwhile, it has been proven that different concentrations of sodium selenite affect various culture properties of LAB. High Se concentration was pernicious, but it could accelerate the growth of $\mathrm{LAB}$ at lower concentrations (Penas et al., 2012a), which was in accordance with the results in our study (Table 1). The growth of both strains was stimulated by sodium selenite under $80 \mu \mathrm{g} / \mathrm{mL}$. However, there also existed some exceptions, such as Ent. durans, which accumulated and tolerated selenite in medium at considerably high level (reaching $176.97 \mathrm{mg} / \mathrm{g}$ in media containing initial amounts of $240 \mathrm{mg} / \mathrm{L}$ of sodium selenite; Pieniz et al., 2013). Interestingly, the biomass from $\mathrm{LAB}$ became redder and redder with the increase of selenite concentration in MRS broth, which indicated higher detoxification efficiency of selenite in the cells (Kieliszek et al., 2016a). In this study, more deepening reddish color around cells of XN-L and XN-S was observed when the selenite concentration increased from $40 \mu \mathrm{g} / \mathrm{mL}$ to $160 \mu \mathrm{g} / \mathrm{mL}$. It could be confirmed that excess selenite can be transformed into Se, imparting a distinct red color (Xia et al., 2007).

Lactic acid bacteria are often used as starter cultures or additives to prevent the survival of other microorganisms in various foods because they provide excellent antimicrobial activity without causing unacceptable sensory changes in foodstuffs (Ghanbari et al., 2013; Pieniz et al., 2014). In this study, CFCS of XN-L, XN$\mathrm{S}, \mathrm{XN}-\mathrm{L}-\mathrm{Se}$, and XN-S-Se showed greater antibacterial activities compared with their corresponding cell suspensions, which indicated that CFCS were the major antibacterial components. It has been reported that CFCS of Strep. thermophilus, Pediococcus acidophilus, Leuconostoc mesenteroides ssp. cremoris, and Lc. lac- tis ssp. lactis showed excellent antibacterial activity against Salmonella paratyphi, L. monocytogenes, Staph. aureus, and E. coli. Subsequently, most antimicrobial substances of LAB, including organic acids, bacteriocins, and exopolysaccharides, were detected and demonstrated in supernatants (Toy et al., 2015; Wang et al., 2015). Research by Cizeikiene et al. (2013) also verified that the organic acids and bacteriocins of Lactobacillus sakei, Pediococcus acidilactici, and Pediococcus pentosaceus could inhibit the growth of Bacillus, Pseudomonas, Listeria, and Escherichia genera in various degrees and have fungicidal and fungistatic activities.

The antibacterial activity of Se-enriched XN-L and $\mathrm{XN}-\mathrm{S}$ was stronger than that of non-Se strains in our study, especially for the bacterial cultures, which might be due to the antibacterial secretion of LAB and Se nanoparticles deposited on the cell surface. Selenium nanoparticles might be one of the most important metabolites in the Se metabolic process in LAB cells. However, there is still a lack of comprehensive and indepth research on Se metabolic pathways in LAB cells. The most thorough study of Se metabolic pathways in food-grade microorganisms was conducted on Seenriched yeast. It has been clarified that there are 3 main steps in the process of Se metabolism in yeast cells. First, selenite (IV) reacts with the reduced glutathione and generates selenodiglutathione (GS-Se-SG) in cells. Second, GS-Se-SG is changed into glutathionyselenol (GS-Se-H) or further translated into hydrogen selenide $\left(\mathrm{H}_{2} \mathrm{Se} / \mathrm{HSe}^{-}\right)$and GSSG. Finally, GS-Se-H is reduced to elemental nanoparticle Se (0) and glutathione (Kieliszek et al., 2015). These elemental Se nanoparticles in our study were observed clearly, which offered the direct visual evidence for the last step [Se (0)] of Se metabolism. Therefore, it was speculated that XN-L and XN-S had similar or the same Se metabolic pathways as yeast.

A recent report from Shoeibi and Mashreghi (2017) indicated that the Se nanoparticles synthesized from sodium selenite by Enterococcus faecalis inhibited the growth of pathogenic gram-positive and gram-negative bacteria. Therefore, in consideration of the antibacterial activity of both $\mathrm{LAB}$ and Se nanoparticles, LAB coupling with Se nanoparticles may achieve a higher antibacterial effect. Previous reports have already shown that Se-enriched LAB had more inhibition effects on pathogenic $E$. coli both in vivo and in vitro (Reid and Burton, 2002). It was also proven that E. coli was inhibited more seriously by CFCS of LAB compared with the control (50.00\%), probiotic bacteria (43.75\%), sodium selenite $(43.36 \%)$, organic Se with prebiotics $(25.00 \%)$, and oxytetracycline $(25.10 \%)$ groups. Moreover, the mortality of mice fed pathogenic E. coli in the group with Se-enriched probiotic bacteria was the 
lowest (18.75\%; Yang et al., 2009). Similarly, Mego et al. (2005b) reported that Se-enriched Ent. faecium 74 could reduce the pathogenic load during inflammatory bowel disease and colon cancer. These data illustrate that Se-enriched LAB have better antibacterial effects than non-Se LAB.

It was also reported that different valences of $\mathrm{Se}$ might have different effects on pathogenic bacteria. The stronger antibacterial effect of Se (0) nanoparticles, one of the most general study objects, has been recognized in many tests (Tran and Webster, 2011; Chudobova et al., 2014; Khiralla and El-Deeb, 2015). Bacteria test results from Wang et al. (2016) also showed that both red and gray Se-coated poly ether ether ketone (PEEK) medical devices significantly inhibited the growth of Pseudomonas aeruginosa compared with uncoated PEEK over 3 d. Furthermore, they showed less bacteria growing on the surface of red Se nanoparticle-coated PEEK than on the surface of gray Se nanorod-coated PEEK after $3 \mathrm{~d}$; this implied that red or gray nanosized Se could be used as potential surface antibacterial coatings to protect PEEK medical devices and directly proved that Se (0) had antibacterial activity (Wang et al., 2016). Pyridyl-1,2,3-selenadiazoles (Lalezari et al., 1974), arylsulfonyl-1,2,3-selenadiazoles (Lalezari et al., 1978), selenosemicarbazide, and its acyl derivatives (Shafiee et al., 1973) also exhibited the strongest activity of growth inhibition against some bacteria and fungi. High-valence selenite was used in Alam et al.'s (2016) antibacterial assay and exhibited a strong spectrum of activity against Bacillus subtilis, Staph. aureus, E. coli, and Klebsiella planticola; a similar property was also found in another study (Kumar et al., 2010). In our study, sodium selenite was used as a control to evaluate the difference between the antibacterial effects of inorganic Se and Se-enriched LAB. The results demonstrated that the antibacterial activity of selenite on the 4 kinds of pathogenic bacteria was not apparent except for Staph. aureus, which was more strongly inhibited by $12 \mu \mathrm{g} / \mathrm{mL}$ of sodium selenite.

We assessed the antibiotic characteristics against pathogenic bacteria of XN-L and XN-S with or without Se enrichment because these CFCS have excellent antibacterial activity. The results showed that the logarithmic and stable phases of pathogenic bacteria were postponed and that the growth velocities were slower, particularly in the logarithmic phases. They further suggested that CFCS from Se-enriched LAB exerted more excellent antibacterial activity, which was in accordance with research by Saraoui et al. (2016) that L. monocytogenes was reduced to 3 to $4 \log \mathrm{cfu} / \mathrm{g}$ when it was cultivated with CFCS of Lactococcus piscium CNCMI4031 for $24 \mathrm{~h}$. The results suggested that the stronger antibacterial activity of Se-enriched LAB could be attributed not only to the strains but also to some kinds of secretions in CFCS such as antibacterial peptides, organic acids, exopolysaccharides, or some new metabolites related to Se. Some organic Se proteins such as selenodiglutathione and Se nanoparticles, which dissolved in the supernatant from the cell surfaces of Se-enriched XN-L and XN-S, might play important roles in antibacterial activity (Li et al., 2002).

High valences of Se could be reduced to element Se (0) nanoparticles by LAB, which might be associated with a detoxification mechanism against excess selenite around cells (Kieliszek et al., 2015; Shoeibi and Mashreghi, 2017). Analysis by scanning electron microscope-EDX showed that element Se, namely Se nanoparticles around the cell surface of XN-L and XN-S with its characteristic peak of $1.42 \mathrm{keV}$, was found in our study (Figure 3). This kind of Se microballoon was also obtained in other studies (Bajaj et al., 2012; Hnain et al., 2013).

The scanning electron micrographs clearly showed that CFCS of Se-enriched XN-L and XN-S induced more serious damage to cell structures of pathogenic bacteria than that of non-Se strains. Compared with the control, morphology analysis of pathogenic bacteria cells mixed with CFCS showed shrunken shape, cytoplasm leakage, and dissolved structure. Morphological analysis from Liu et al.'s (2016) research also showed that bifidocin of probiotic bacteria induced transformations in morphology and intracellular organization of $E$. coli cells. The outstanding antibacterial activity of Se-enriched LAB was intuitively exhibited in this study. However, the antibacterial mechanism of Se-enriched strains was not clear at the molecular level, so further investigation and exploration should be carried out.

\section{CONCLUSIONS}

The present study indicated that an effective way to prepare the Se-enriched $L b$. delbrueckii ssp. bulgaricus and Strep. thermophilus would be to cultivate them in MRS broth with suitable concentrations of sodium selenite. Compared with non-Se strains, Se-enriched LAB showed higher antibacterial activities against 4 kinds of common food-borne pathogenic bacteria, which significantly reduced the growth rate and damaged the cell structures of the pathogenic bacteria. The scanning electron microscopy-EDX analysis showed that selenite could be reduced to elemental Se by XN-L and XN-S; therefore, it indicated that these 2 Se-enriched LAB had potential commercial advantages for their fermented products, which could not only provide probiotic bacteria and absorbable elemental or organic Se but also endow higher antibacterial activity to pathogens. 


\section{ACKNOWLEDGMENTS}

This work was supported by grant no. 2016NY-148 from the Department of Science and Technology of Shaanxi Province (Xi'an, China).

\section{REFERENCES}

Alam, M. F., M. M. Safhi, S. S. Moni, and A. Jabeen. 2016. In vitro antibacterial spectrum of sodium selenite against selected human pathogenic bacterial strains. Scientifica (Cairo) 2016:9176273.

Alzate, A., B. Cañas, S. Pérez-Munguía, H. Hernández-Mendoza, C. Pérez-Conde, A. M. Gutiérrez, and C. Cámara. 2007. Evaluation of the inorganic selenium biotransformation in selenium-enriched yogurt by HPLC-ICP-MS. J. Agric. Food Chem. 55:9776-9783.

Alzate, A., A. Fernández-Fernández, M. C. Pérezconde, A. M. Gutiérrez, and C. Cámara. 2008. Comparison of biotransformation of inorganic selenium by Lactobacillus and Saccharomyces in lactic fermentation process of yogurt and kefir. J. Agric. Food Chem. $56: 8728-8736$

Alzate, A., M. C. Pérez-Conde, A. M. Gutiérrez, and C. Cámara. 2010. Selenium-enriched fermented milk: A suitable dairy product to improve selenium intake in humans. Int. Dairy J. 20:761-769.

Amer, A. A., A. S. Aiad, and M. A. Abdallah. 2010. Effect of yogurt processing and ice cream manufacture on viability of some foodborne bacteria. Assiut Vet. Med. J. 56:108-119.

Andreoni, V., M. M. Luischi, L. Cavalca, D. Erba, and S. Ciappellano. 2000a. Selenite tolerance and accumulation in the Lactobacillus species. Ann. Microbiol. 50:77-88.

Andreoni, V., L. M. Moro, L. Cavalca, D. Erba, and S. Ciappellano. 2000b. Selenite tolerance and accumulation in the Lactobacillus species. Ann. Microbiol. 50:77-88.

Bajaj, M., S. Schmidt, and J. Winter. 2012. Formation of Se (0) nanoparticles by Duganella sp and Agrobacterium sp. isolated from Se-laden soil of North-East Punjab, India. Microb. Cell Fact. 11:64.

Bajpai, V. K., J. H. Han, I. A. Rather, C. Park, J. Lim, W. K. Paek, J. S. Lee, J. I. Yoon, and Y. H. Park. 2016. Characterization and antibacterial potential of lactic acid bacterium Pediococcus pentosaceus 411 isolated from freshwater fish Zacco koreanus. Front. Microbiol. 7:15

Bernini, V., E. Dalzini, C. Lazzi, B. Bottari, S. Bisotti, M. Fontana, and E. Neviani. 2015. A multi-sampling approach to evaluate an infrared surface treatment for reducing Listeria monocytogenes contamination on whole Gorgonzola cheese rinds. Food Control $55: 75-81$

Chudobova, D., K. Cihalova, S. Dostalova, B. Ruttkaynedecky, M. A. Merlos Rodrigo, K. Tmejova, P. Kopel, L. Nejdl, J. Kudr, and J. Gumulec. 2014. Comparison of the effects of silver phosphate and selenium nanoparticles on Staphylococcus aureus growth reveals potential for selenium particles to prevent infection. FEMS Microbiol. Lett. 351:195.

Cizeikiene, D., G. Juodeikiene, A. Paskevicius, and E. Bartkiene. 2013. Antimicrobial activity of lactic acid bacteria against pathogenic and spoilage microorganism isolated from food and their control in wheat bread. Food Control 31:539-545.

Cock, I. E. 2007. Antibacterial activity of selected Australian native plant extracts. Internet J. Microbiol. 4:2.

Dalie, D. K. D., A. M. Deschamps, and F. Richard-Forget. 2010. Lactic acid bacteria-Potential for control of mould growth and mycotoxins: A review. Food Control 21:370-380.

Dalzini, E., V. Bernini, B. Bertasi, P. Daminelli, M. N. Losio, and G. Varisco. 2016. Survey of prevalence and seasonal variability of Listeria monocytogenes in raw cow milk from Northern Italy. Food Control 60:466-470.

Deng, Y., C. Man, Y. Fan, Z. Wang, L. Li, H. Ren, W. Cheng, and Y. Jiang. 2015. Preparation of elemental selenium-enriched fermented milk by newly isolated Lactobacillus brevis from kefir grains. Int. Dairy J. 44:31-36.
Esena, R. K., and E. Owusu. 2013. Quality of cooked foods in urban schools in Ghana: Review of food borne diseases and health implications. Int. J. Sci. Technol. Res. 2:267.

Ghanbari, M., M. Jami, K. J. Domig, and W. Kneifel. 2013. Seafood biopreservation by lactic acid bacteria-A review. Lebensm. Wiss. Technol. 54:315-324.

Guo, Y., D. Pan, H. Li, Y. Sun, X. Zeng, and B. Yan. 2013. Antioxidant and immunomodulatory activity of selenium exopolysaccharide produced by Lactococcus lactis ssp. lactis. Food Chem. 138:84-89.

Hnain, A.. J. Brooks, and D. D. Lefebvre. 2013. The synthesis of elemental selenium particles by Synechococcus leopoliensis. Appl. Microbiol. Biotechnol. 97:10511-10519.

Institute of Medicine. 2000. Dietary Reference Intakes for Vitamin C, Vitamin E, Selenium, and Carotenoids. National Academies Press, Washington, DC.

Kessi, J., M. Ramuz, E. Wehrli, M. Spycher, and R. Bachofen. 1999. Reduction of selenite and detoxification of elemental selenium by the phototrophic bacterium Rhodospirillum rubrum. Appl. Environ. Microbiol. 65:4734.

Khiralla, G. M., and B. A. El-Deeb. 2015. Antimicrobial and antibiofilm effects of selenium nanoparticles on some foodborne pathogens. Lebensm. Wiss. Technol. 63:1001-1007.

Kieliszek, M., and S. Blazejak. 2013. Selenium: Significance, and outlook for supplementation. Nutrition 29:713-718.

Kieliszek, M., S. Blazejak, A. Bzducha-Wrobel, and A. Kurcz. 2016a. Effects of selenium on morphological changes in Candida utilis ATCC 9950 yeast cells. Biol. Trace Elem. Res. 169:387-393.

Kieliszek, M., S. Blazejak, I. Gientka, and A. Bzducha-Wrobel. 2015. Accumulation and metabolism of selenium by yeast cells. Appl. Microbiol. Biotechnol. 99:5373-5382.

Kieliszek, M., S. Blazejak, and M. Placzek. 2016b. Spectrophotometric evaluation of selenium binding by Saccharomyces cerevisiae ATCC MYA-2200 and Candida utilis ATCC 9950 yeast. J. Trace Elem. Med. Biol. 35:90-96.

Kim, D. H., D. Jeong, H. Kim, I. B. Kang, J. W. Chon, K. Y. Song, and K. H. Seo. 2016. Antimicrobial activity of kefir against various food pathogens and spoilage bacteria. Korean J. Food Sci. Anim. Resour. 36:787-790.

Kouamé-Sina, S. M., K. Makita, S. Costard, D. Grace, A. Dadie, M. Dje, and B. Bonfoh. 2012. Hazard identification and exposure assessment for bacterial risk assessment of informally marketed milk in Abidjan, Cote d'Ivoire. Food Nutr. Bull. 33:223-234.

Kumar, B. S., S. G. Tiwari, A. Kunwar, N. Amrita, G. Sivaram, Z. Abid, A. Ahmad, A. A. Khan, and K. I. Priyadarsini. 2010. Antiunlcer and antimicrobial activities of sodium selenite against $\mathrm{He}$ licobacter pylori: In vitro and in vivo evaluation. Scand. J. Infect. Dis. $42: 266-274$

Lalezari, I., A. Shafiee, J. Khorrami, and A. Soltani. 1978. Selenium heterocycles XXII: Synthesis and antibacterial antifungal activities of arylsulfonyl-1,2,3-selenadiazoles. J. Pharm. Sci. 67:1336-1338.

Lalezari, I., A. Shafiee, and S. Yazdany. 1974. Selenium heterocycles. $\mathrm{X}$. Synthesis and antibacterial activity of pyridyl-1,2,3-thiadiazoles and pyridyl-1,2,3-selenadiazoles. J. Pharm. Sci. 63:628-629.

Lee, S. C., R. B. Billmyre, A. Li, S. Carson, S. M. Sykes, E. Y. Huh, P. Mieczkowski, D. C. Ko, C. A. Cuomo, and J. Heitman. 2014. Analysis of a food-borne fungal pathogen outbreak: Virulence and genome of a Mucor circinelloides isolate from yogurt. MBio 5:e01390-14.

Li, X., Y. Liu, J. Wu, H. G. Liang, and S. S. Qu. 2002. Microcalorimetric study of Staphylococcus aureus growth affected by selenium compounds. Thermochim. Acta 387:57-61.

Liu, G., Z. Song, X. Yang, Y. Gao, C. Wang, and B. Sun. 2016. Antibacterial mechanism of bifidocin A, a novel broad-spectrum bacteriocin produced by Bifidobacterium animalis BB04. Food Control 62:309-316

Mater, D. D. G., L. Bretigny, O. Firmesse, M. J. Flores, A. Mogenet, J. L. Bresson, and G. Corthier. 2005. Streptococcus thermophilus and Lactobacillus delbrueckii subsp. bulgaricus survive gastrointestinal transit of healthy volunteers consuming yogurt. FEMS Microbiol. Lett. 250:185-187. 
McAuley, C. M., K. McMillan, S. C. Moore, N. Fegan, and E. M. Fox. 2014. Prevalence and characterization of food borne pathogens from Australian dairy farm environments. J. Dairy Sci. 97:74027412 .

Mego, M., J. Májek, R. Konceková, L. Ebringer, S. Cierniková, P. Rauko, M. Kovác, J. Trupl, P. Slezák, and V. Zajac. 2005a. Intramucosal bacteria in colon cancer and their elimination by probiotic strain Enterococcus faecium M-74 with organic selenium. Folia Microbiol. (Praha) 50:443.

Mego, M., J. Májek, R. Konceková, L. Ebringer, S. Cierniková, P. Rauko, M. Kovác, J. Trupl, P. Slezák, and V. Zajac. 2005b. Intramucosal bacteria in colon cancer and their elimination by probiotic strain Enterococcus faecium M-74 with organic selenium. Folia Microbiol. (Praha) 50:443-447.

Mogna, L., S. Nicola, M. Pane, P. Lorenzini, G. Strozzi, and G. Mogna. 2012. Selenium and zinc internalized by Lactobacillus buchneri Lb26 (DSM 16341) and Bifidobacterium lactis Bb1 (DSM 17850) improved bioavailability using a new biological approach. J. Clin. Gastroenterol. 46:S41-S45.

Mølbak, K., P. S. Mead, and P. M. Griffin. 2002. Antimicrobial therapy in patients with Escherichia coli O157:H7 infection. J. Am. Med. Assoc. 288:1014-1016.

Navarro-Alarcón, M., and M. C. Lopez-Martinez. 2000. Essentiality of selenium in the human body: Relationship with different diseases. Sci. Total Environ. 249:347-371.

Olsen, S. J., L. C. MacKinnon, J. S. Goulding, N. H. Bean, and L. Slutsker. 2000. Surveillance for foodborne-disease outbreaksUnited States, 1993-1997. MMWR CDC Surveill. Summ. 49:1-62.

Palomo, M., A. M. Gutierrez, M. C. Perez-Conde, C. Camara, and Y. Madrid. 2014. Se metallomics during lactic fermentation of Seenriched yogurt. Food Chem. 164:371-379.

Penas, E., C. Martinez-Villaluenga, J. Frias, M. Jose Sanchez-Martinez, M. Teresa Perez-Corona, Y. Madrid, C. Camara, and C. Vidal-Valverde. 2012a. Se improves indole glucosinolate hydrolysis products content, Se-methylselenocysteine content, antioxidant capacity and potential anti-inflammatory properties of sauerkraut. Food Chem. 132:907-914.

Penas, E., C. Martinez-Villaluenga, J. Frias, M. J. Sanchez-Martinez, M. T. Perez-Corona, Y. Madrid, C. Camara, and C. Vidal-Valverde. $2012 \mathrm{~b}$. Se improves indole glucosinolate hydrolysis products content, Se-methylselenocysteine content, antioxidant capacity and potential anti-inflammatory properties of sauerkraut. Food Chem. 132:907-914.

Pieniz, S., R. Andreazza, J. Q. Pereira, F. A. de Oliveira Camargo, and A. Brandelli. 2013. Production of selenium-enriched biomass by Enterococcus durans. Biol. Trace Elem. Res. 155:447-454.

Pieniz, S., R. Andreazza, T. Anghinoni, F. Camargo, and A. Brandelli. 2014. Probiotic potential, antimicrobial and antioxidant activities of Enterococcus durans strain LAB18s. Food Control 37:251-256.

Reid, G., and J. Burton. 2002. Use of Lactobacillus to prevent infection by pathogenic bacteria. Microbes Infect. 4:319-324.

Saraoui, T., P. A. Fall, F. Leroi, J.-P. Antignac, S. Chereau, and M. F. Pilet. 2016. Inhibition mechanism of Listeria monocytogenes by a bioprotective bacteria Lactococcus piscium CNCM I-4031. Food Microbiol. 53:70-78.
Schillinger, U., and F. K. Lucke. 1989. Antibacterial activity of Lactobacillus sake isolated from meat. Appl. Environ. Microbiol. 55:1901-1906.

Sezonov, G., D. Joseleaupetit, and R. D'Ari. 2007. Escherichia coli physiology in Luria-Bertani broth. J. Bacteriol. 189:8746.

Shafiee, A., I. Lalezari, S. Yazdany, and A. Pournorouz. 1973. Selenium heterocycles VIII: Synthesis and antibacterial activity of selenosemicarbazide and 1,3,4-selenadiazolylcarbamic acid esters. J. Pharm. Sci. 62:839-840.

Shoeibi, S., and M. Mashreghi. 2017. Biosynthesis of selenium nanoparticles using Enterococcus faecalis and evaluation of their antibacterial activities. J. Trace Elem. Med. Biol. 39:135-139.

Smaoui, S., L. Elleuch, W. Bejar, I. Karray-Rebai, I. Ayadi, B. Jaouadi, F. Mathieu, H. Chouayekh, S. Bejar, and L. Mellouli. 2010. Inhibition of fungi and gram-negative bacteria by bacteriocin BacTN635 produced by Lactobacillus plantarum sp. TN635. Appl. Biochem. Biotechnol. 162:1132-1146.

Suhajda, A., J. Hegoczki, B. Janzso, I. Pais, and G. Vereczkey. 2000. Preparation of selenium yeasts I. Preparation of selenium-enriched Saccharomyces cerevisiae. J. Trace Elem. Med. Biol. 14:43-47.

Tajik, H., S. M. Rohani, and M. Moradi. 2007. Detection of aflatoxin M1 in raw and commercial pasteurized milk in Urmia, Iran. Pakistan J. Biol. Sci. 10:4103.

Tayel, A. A., and W. F. El-Tras. 2010. Anticandidal activity of pomegranate peel extract aerosol as an applicable sanitizing method. Mycoses 53:117-122.

Timm, C. D., D. T. Silva, P. A. Dias, and R. D. C. Conceicao. 2013. Pathogenic microorganisms survival in ambrosia. Semin. Cienc. Agrar. 34:1829-1833.

Toy, N., F. Ozogul, and Y. Ozogul. 2015. The influence of the cell free solution of lactic acid bacteria on tyramine production by food borne-pathogens in tyrosine decarboxylase broth. Food Chem. 173:45-53.

Tran, P. A., and T. J. Webster. 2011. Selenium nanoparticles inhibit Staphylococcus aureus growth. Int. J. Nanomed. 6:1553-1558.

Wang, J., X. Zhao, Y. Yang, A. Zhao, and Z. Yang. 2015. Characterization and bioactivities of an exopolysaccharide produced by $L a c$ tobacillus plantarum YW32. Int. J. Biol. Macromol. 74:119-126.

Wang, Q., A. M. Jaramillo, J. J. Pavon, and T. J. Webster. 2016. Red selenium nanoparticles and gray selenium nanorods as antibacterial coatings for PEEK medical devices. J. Biomed. Mater. Res. Part B Appl. Biomater. 104:1352-1358.

Xia, S. K., L. Chen, and J. Q. Liang. 2007. Enriched selenium and its effects on growth and biochemical composition in Lactobacillus bulgaricus. J. Agric. Food Chem. 55:2413-2417.

Yang, J., K. Huang, S. Qin, X. Wu, Z. Zhao, and F. Chen. 2009. Antibacterial action of selenium-enriched probiotics against pathogenic Escherichia coli. Dig. Dis. Sci. 54:246-254.

Yang, J., Y. Li, L. Zhang, M. Fan, and X. Wei. 2017. Response surface design for accumulation of selenium by different lactic acid bacteria. 3 Biotech 7:52.

Zhou, N., J. X. Zhang, M. T. Fan, J. Wang, G. Guo, and X. Y. Wei. 2012. Antibiotic resistance of lactic acid bacteria isolated from Chinese yogurts. J. Dairy Sci. 95:4775-4783. 